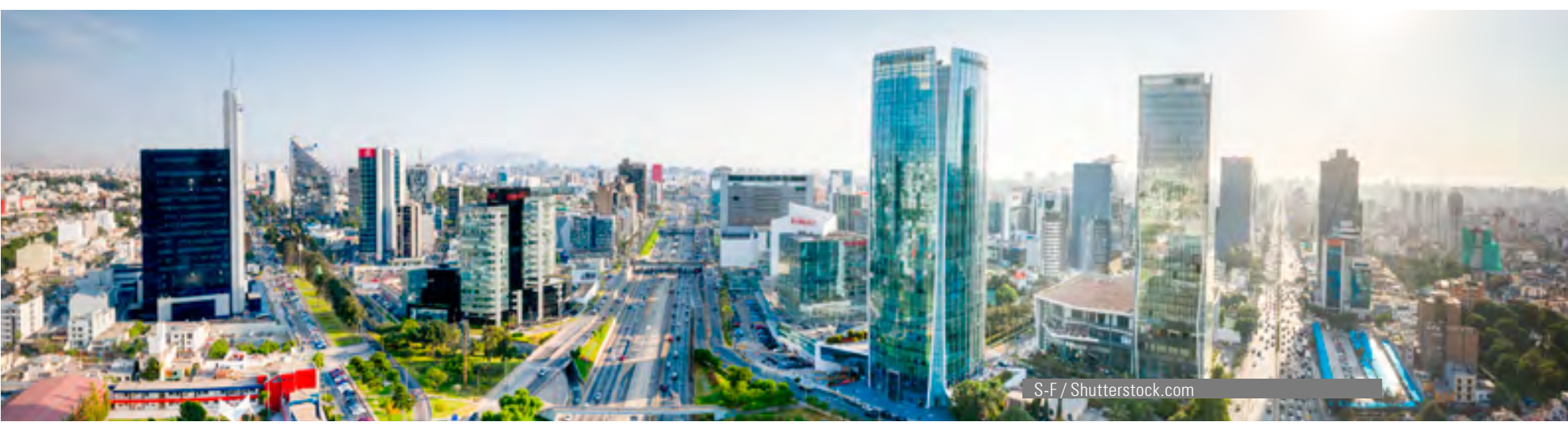

\title{
The impact of culture on the management of subsidiary organizations: The case of Viettel in Peru
}

\section{El impacto de la cultura de gestión en las subsidiaras: el caso de Viettel en Perú}

Gareth H Rees

Universidad ESAN

grees@esan.edue.pe

Orcid: orcid.org/0000-0002-8648-3626

Oswaldo Morales Tristán

Universidad ESAN

omorales@esan.edu.pe

Orcid: orcid. org/0000-0002-5298-9733

\section{Gladys Alosilla Cruzado \\ Universidad ESAN \\ gladys.alosilla@gmail.com}

\section{Sandra Guizado Vásquez \\ Universidad ESAN \\ milagros.guizado@gmail.com}

\section{Bárbara Laos Raffo}

Universidad ESAN

barbara.laos.raffo@gmail.com

\section{Orlando López Melgar \\ Universidad ESAN \\ orlandojp89@gmail.com}

Recibido: 3 de septiembre 2020.

Aprobado: 9 de octubre 2020.

Publicado: 16 de diciembre 2020

\begin{abstract}
As south-south investments increase so do the issues experienced by investing companies. One of these is the impact of culture. This article analyzes the effects of the subsidiary country culture on an investing firm's organizational culture and the managerial practices used to address them. Data is gathered from cultural databases, a company-wide survey and semi structured interviews. Descriptive statistics are used to reveal country and organizational culture differences, with content analysis to expose management responses.

There is a clear difference between the firm's Vietnamese and Peruvian workers, with the company's practices more amenable to the Vietnamese employees. Recognition of this has resulted in a number of initiatives to reduce its impact. The study's results offer suggestions that may be valued by other foreign companies interested in operating in Peru and may be especially relevant to Southeast Asia and Asian companies interested in investing in or looking to start operations in Latin America.
\end{abstract}

\section{Keywords:}

Organizational culture, National culture, Cultural differences, Subsidiary company, Vietnam, Peru, Latin America

\section{Resumen}

A medida que aumentan las inversiones sur-sur, también incrementan los problemas experimentados por las empresas inversoras. Uno de ellos es el impacto de la cultura. Este artículo analiza los efectos de la cultura del país filial en la cultura organizativa de una empresa inversora y las prácticas de gestión utilizadas para abordarlos. Los datos se recopilan de bases de datos culturales (Hofstede), una encuesta para analizar cultura organizacional (Modelo de Denison) y entrevistas semi-estructuradas. 
Existen diferencias culturales entre los trabajadores vietnamitas y peruanos. Las prácticas de la empresa favorecen más a los empleados vietnamitas debido a su cultura organizacional. Los reconocimientos de estas diferencias han generado iniciativas para reducir el impacto de la cultura nacional peruana sobre la cultura organizacional de la empresa. Las empresas extranjeras que operan en Perú, especialmente las del sudeste asiático y de Asia interesadas en invertir en América Latina pueden usar esto como un ejemplo para abordar las diferencias culturales nacionales y su impacto sobre las culturas organizacionales.

\section{Palabras clave:}

Cultura organizacional, cultura nacional, diferencia cultural, compañía subsidiaria, Vietnam, Perú, América Latina

\section{Introduction}

As the world became increasingly globalized around the turn of the century, firms from emerging economies began investing outside their borders. While Foreign Direct Investment (FDI) flows remain dominated by firms from developed economies, global FDI flows are increasingly being made by firms from emerging economies (UNCTAD, 2019a; UNCTAD, 2019b). It is estimated that this so called south-south investment will generate one-third of global FDI outflows by 2025 (Saha et al., 2020). As such, trade and FDI flows between Asia and Latin America are on the rise, fueled in part by bilateral trade agreements together with the recent completion of the Comprehensive and Progressive Agreement for Trans-Pacific Partnership (CPTPP), a free trade agreement between eleven countries around the Pacific Rim: Canada, Mexico, Peru, Chile, New Zealand, Australia, Brunei, Singapore, Malaysia, Vietnam and Japan. The agreement's Latin American member nations, namely Mexico, Chile and Peru, are set to expand trade gains and receive preferential access to its Asian members (Ciuriak et al., 2017).

With increased south-south trade and investment, important questions arise not just regarding the quantity of trade and investment, but regarding its quality and the "actors and relationships [...] involved, and who gains or loses" (M. Leach in Saha et al., 2020, p.iv). Thus, as emerging economy firms enter other emerging markets, they come face to face with host country operating risks. One of these risks has to do with culture and the management of cultural differences between host and subsidiary country personnel to create an optimal organizational culture and ensure subsidiary performance (Singh et al., 2019).

In Culture and Organizations. Software of the Mind, Hofstede (2005) states that "managers and leaders, and the people they work with, are part of national societies. If we want to understand their behavior, we have to understand their societies" (p.20). In the same book, Hofstede also emphasizes that "research results about national cultures and their dimensions proved to be only partly useful for the understanding of organizational cultures" (p.36). Thus, according to Hofstede, both the values of the host country and the societal values of the foreign company must be understood to be able to conduct an unbiased and reliable analysis of a firm's organizational dynamics.

However, this intersection of national culture, organizational culture and cultural difference is acknowledged as being under researched (Khan \& Law, 2018), with authors suggesting a need for more multi-level research (Schnieder et al., 2013) to clarify the effect of culture's on the workplace (Kim \& McLean, 2014; Dartey-Baah, 2011), the workforce, and the firm's performance (Cartwright \& Cooper, 1993). 
As such, this article intends to add to the literature on the practicalities of south-south investment and the management of subsidiary firm culture through an analysis of the case of a Vietnamese telecommunications subsidiary operating in Peru. This case was chosen as it reveals situations and responses that investing companies from Asia may experience in Latin America and provides an outline of the company's responses to adapt its operations to this context, which other firms with south-south investments may wish to emulate.

Thus, the article begins with a summary of the underlying theories of culture and its national and organizational constructs. Then, the case study context is introduced followed by the data and methods used to identify the results. The results are then presented as (i) cultural differences between the two countries, (ii) their effects on organizational culture and (iii) responses made by the company to maintain performance. These results are briefly discussed, with conclusions presented to close out the article.

\section{The Study of Culture in Nations and Organizations}

Culture is seen as having an important role in defining the value of work and its priority within a society (Hofstede, 1980; Pelled \& Xin, 1997; Schneider \& Barsoux, 1997; Trompenaars \& Hampden-Turner, 1998; Holden, 2002). The definition of culture has a rich history, with Tylor (1871) defining it as a group of beliefs, customs, habits, knowledge, art, norms and laws acquired by people who are members of a particular society. These shared elements ensure that cultures are unique and continued by transmission to following generations (Arbaiza Fermini, 2014). This sharing and communication of culture across societies has also been described as a programming of the mind (Hofstede, 1980) and while variations regarding cultures (Au, 1999) or subcultures may exist within societies, the differences between these tend to be less than those between nations (Schwartz, 2004).

Hofstede pioneered the measurement of cultural values with his global study on the value of work (Hofstede, 1980) producing a framework that allows classifying countries on six dimensions (see Table 1).

\section{Table 1. Hofstede's cultural values dimensions}

Dimension

Power Distance

Individualism versus

Collectivism (IDV)

Masculinity versus

Femininity (MAS)
Description

How a society handles inequalities among people, where a large degree of Power Distance has people accepting a hierarchical order in which everybody has a place while in a low power distance society people strive to equalize the power distribution and demand justification for inequalities of power.

The high score of this dimension, called Individualism, is a preference for a loosely-knit social framework in which individuals are expected to take care of only themselves and their immediate families. Its opposite is Collectivism (low score), represents a society in which individuals can expect their relatives or members of a particular ingroup to look after them in exchange for unquestioning loyalty.

The Masculinity side of this dimension represents a more competitive society, which expresses achievement, heroism, assertiveness, and material rewards for success. Its opposite, Femininity, stands for a more consensus-oriented society with preferences for cooperation, modesty, caring for the weak and quality of life. 
Dimension

\begin{tabular}{|l|l|}
\hline $\begin{array}{l}\text { Uncertainty Avoid- } \\
\text { ance Index (UAI) }\end{array}$ & $\begin{array}{l}\text { The Uncertainty Avoidance dimension expresses the degree to which } \\
\text { the members of a society feel uncomfortable with uncertainty and am- } \\
\text { biguity. } \\
\text { Strong UAI countries maintain rigid codes of belief and behavior, and } \\
\text { are intolerant of unorthodox behavior and ideas. Weak UAI societies } \\
\text { maintain a more relaxed attitude in which practice counts more than } \\
\text { principles. }\end{array}$ \\
\hline $\begin{array}{l}\text { Long Term Orien- } \\
\text { tation versus Short } \\
\text { Term Normative Ori- } \\
\text { entation (LTO) }\end{array}$ & $\begin{array}{l}\text { This represents how a society maintains links with its own past while } \\
\text { dealing with the challenges of the present and the future. Societies with } \\
\text { a low LTO prefer to maintain traditions and norms while viewing societal } \\
\text { change with suspicion, while high LTO societies are more pragmatic, } \\
\text { encourage thrift and education as a way to prepare for the future. }\end{array}$ \\
\hline $\begin{array}{l}\text { Indulgence versus } \\
\text { Restraint (IVR) }\end{array}$ & $\begin{array}{l}\text { Indulgence stands for gratification of basic and natural human drives for } \\
\text { enjoying life and having fun, while restraint suppresses gratification of } \\
\text { needs and regulation by strict social norms. }\end{array}$ \\
\hline
\end{tabular}

Source: https://hi.hofstede-insights.com/national-culture

The configuration of a country's values has an effect on how that society views the purpose of work and the relative emphasis placed on work-related incentives and payment (Schwartz, 1999). Thus, the value placed on the intrinsic and extrinsic rewards people get from work and the financial and non-financial incentives that firms use, will vary depending on cultural norms (Schneider \& Barsoux, 1997). As such, there are links between a country's national culture and a firm's organizational values resulting from that culture (Hofstede, 1985), and its organizational practices also tend to be linked to national cultural norms (Omar \& Urteaga, 2010).

However, management techniques favored by one national culture will not necessarily be seen as appropriate in another (Hofstede, 1984). This has implications for companies as they become more global, where national cultural differences will impact organizational culture, workforces and firm performance (Cartwright \& Cooper, 1993), suggesting that multinational firms will benefit more from understanding and coordinating the range of cultural values that exist within their subsidiaries, rather than trying to enforce a single culture common to all (Ralston et al., 2008).

However, as organizations have their own histories, values, beliefs and identities, their organizational cultures may be different, even if they are from the same country (Serna, 2008). An organization's culture will be made evident by the models of behavior, ideas and values shared by its members and expressed through what people say and do in the workplace (Koontz, 2007). Organizational culture is initially conceived and generated by a firm's founders as a means to transfer the drive of the individual into a collective purpose and commitment towards the organization's members (Pettigrew, 1979; Ehrhart et al., 2014), and has a major impact on how the group initially defines and solves adaptation and integration problems (Schein, 1992). The resulting culture also reflects and reinforces structures and social roles that its members play and helps create special meaning for them within that company's workplace (García Álvarez, 2006).

An organization's culture will therefore embody symbols such as the firm's identity and brands, its rituals and the rules and norms to be followed, and its organizational heroes or role models (Olie, 1990). Thus, an organization's culture is a reflection of its identity and essence, linking its initial orientation with its current behavioral guidelines, shared values and shared beliefs (Capriotti, 2009). Some of these attributes will be visible, while others, such as a firm's 
(2013) perspective on the culture the firm has and using the Denison Organizational Cultural Model (Denison Consulting, 2019) and, finally, applying the view of the firm as a culture, responses to interview questions that reveal how the firm manages the firm's cultural issues are analyzed.

A number of studies have confirmed the Denison model's value for determining the relationship between organizational culture and the different factors of firm performance and improvement in Latin America. It has been used to find contrasting organizational cultures between industries, to diagnose leadership improvement attributes and identify possible adjustments for addressing performance and workforce issues (Martinez Ramos, et al., 2011), to identify degrees of correlation between culture and organizational effectiveness (Reyes-Martínez, et al., 2017), and to correlate organizational culture and workforce performance (Montero Pacheco, 2018).

Denison's Organizational Culture model (see Fig. 1) is considered appropriate for this type of study as it enables comparative generalizations of an organization's culture (Balcazar Guerra, 2018). The model depicts organizational culture across two dimensions - External-Internal and Flexible-Stable. These dimensions further define four quadrants named Involvement, Consistency, Adaptability and Mission, which enables assessing an organization's performance in terms of its Growth, Innovation and Customer Satisfaction, Quality and Employee Satisfaction, and Efficiency and Profitability (Denison Consulting, 2019). Table five in the appendix at the end of the article provides an in-depth description of the quadrants and their indices.

\section{Figure 1. The Denison Organizational Culture Model}

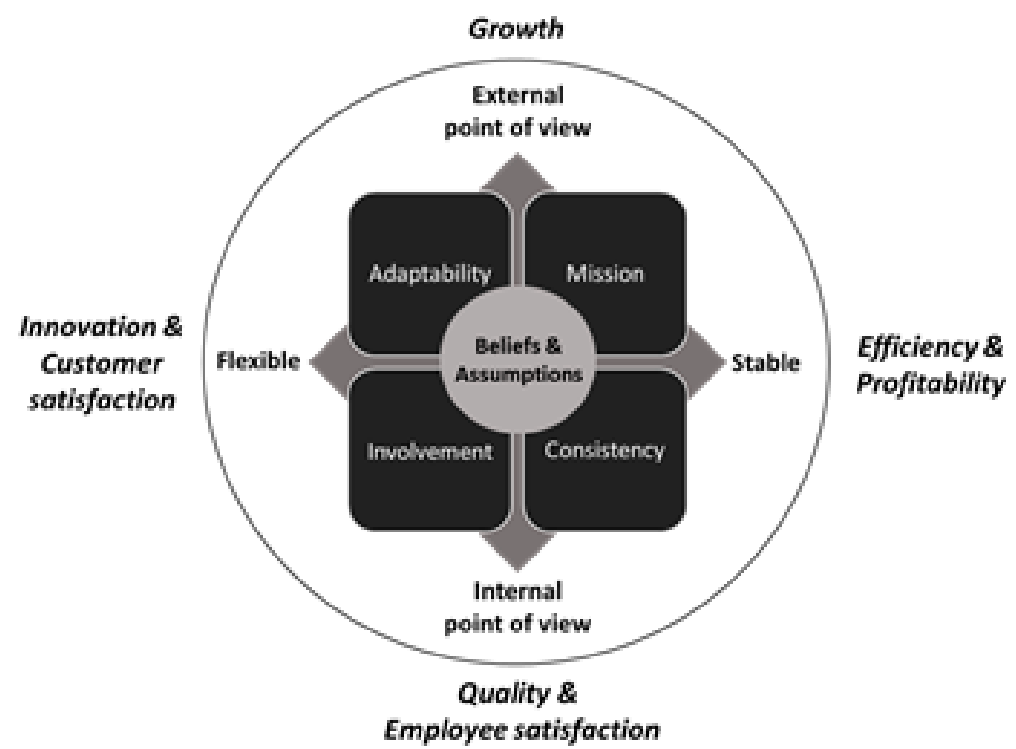

Source: Adapted from Denison Consulting (2019)

\subsection{Study Data}

To investigate national cultural differences, the two countries' national culture dimensional data from Hofstede's database were compared. Then, to assess organizational culture, data were gathered using Denison's survey of Bitel's workforce. At the time of the survey, Bitel had 1506 employees, 106 of which were Vietnamese, and the remainder included 1,381 Peruvian employ- 
ees and 15 other nationalities, leading to a survey sample of 99 Vietnamese employees and 249 Peruvians. Responses were collected through an online survey sent to workers over the company intranet. This survey contained the model's 48 questions which were to be answered using a 3-option scale of agree, neutral or disagree. These data were processed in Excel spreadsheets to produce the spider charts found in Figure 2 and enable analysis. Third, data to understand the focal firm's culture, workforce differences and its managerial responses were gathered through semi structured interviews, which followed a pre-determined question guide that canvassed differences in adaptability, behavior and conformity of the workforce with nine (9) key informants, who provided information directly related to the focus of the study and the role that they have within the focal firm (Palys, 2008). Interviews lasted approximately 45 minutes each. The key informant responses were recorded in situ, transcribed and analyzed to provide key themes (Julien, 2008) about the focal firms' culture. Table two provides limited information on the key informants, respecting Bitel's wish for respondent confidentiality.

Table 2. Key Informants

\begin{tabular}{|c|l|l|l|}
\hline Interviewee & \multicolumn{1}{|c|}{ Area of Work } & \multicolumn{1}{|c|}{ Nationality } & \multicolumn{1}{c|}{ Years at Bitel } \\
\hline 1 & Management Division & Peruvian & 4 years \\
\hline 2 & Commercial Division & Peruvian & 4 years \\
\hline 3 & Commercial Division & Peruvian & 5 years \\
\hline 4 & Management Division & Peruvian & 2 years \\
\hline 5 & Management Division & Vietnamese & 3 years \\
\hline 6 & Management Division & Vietnamese & 3 years \\
\hline 7 & Management Division & Vietnamese & 1 years \\
\hline 8 & Commercial Division & Vietnamese & 2 years \\
\hline 9 & Commercial Division & Vietnamese & 4 years \\
\hline
\end{tabular}

Source: Authors

\section{Results}

The results of the study's three parts are presented in the following separate subsections, beginning with national cultural differences, followed by Bitel's organizational culture and finally, the results of the key informant interviews.

\subsection{Examining National Cultural Differences between Peru and Vietnam}

While the two countries have different antecedents, there are certain similarities as well as differences that can be observed in their cultural dimension scores (see Table 3). 
Table 3. Cultural Dimension scores for Peru and Vietnam

\begin{tabular}{|l|c|c|c|}
\hline \multicolumn{1}{|c|}{ Dimension } & Peru & Vietnam & Difference* \\
\hline Power Distance & 64 & 70 & 6 \\
\hline Individualism & 16 & 20 & 4 \\
\hline Masculinity & 42 & 40 & 2 \\
\hline $\begin{array}{l}\text { Uncertainty Avoid- } \\
\text { ance }\end{array}$ & 87 & 30 & 57 \\
\hline Long-term Orientation & 25 & 57 & 32 \\
\hline Indulgence & 46 & 35 & 9 \\
\hline
\end{tabular}

Source: https://hi.hofstede-insights.com/national-culture

Note: * Differences are presented as absolute values

Table 3 reveals two major differences between the countries. The first is the uncertainty avoidance dimension, which is much larger for Peru than Vietnam, and the second is the long-term orientation dimension, which has also been related to certain aspects of uncertainty avoidance (Nguyen \& Truong, 2016). Thus, it is expected that these differences will also reveal themselves in behavioral and performance traits of the workers.

\subsection{Examining Bitel's Organizational Culture}

Three charts were produced from the Denison survey data to enable a visual comparison (see Figure 2), one for Bitel as a whole, one for Vietnamese nationals and one for Peruvian workers.

\section{Figure 2. Organizational Culture Charts for Bitel}
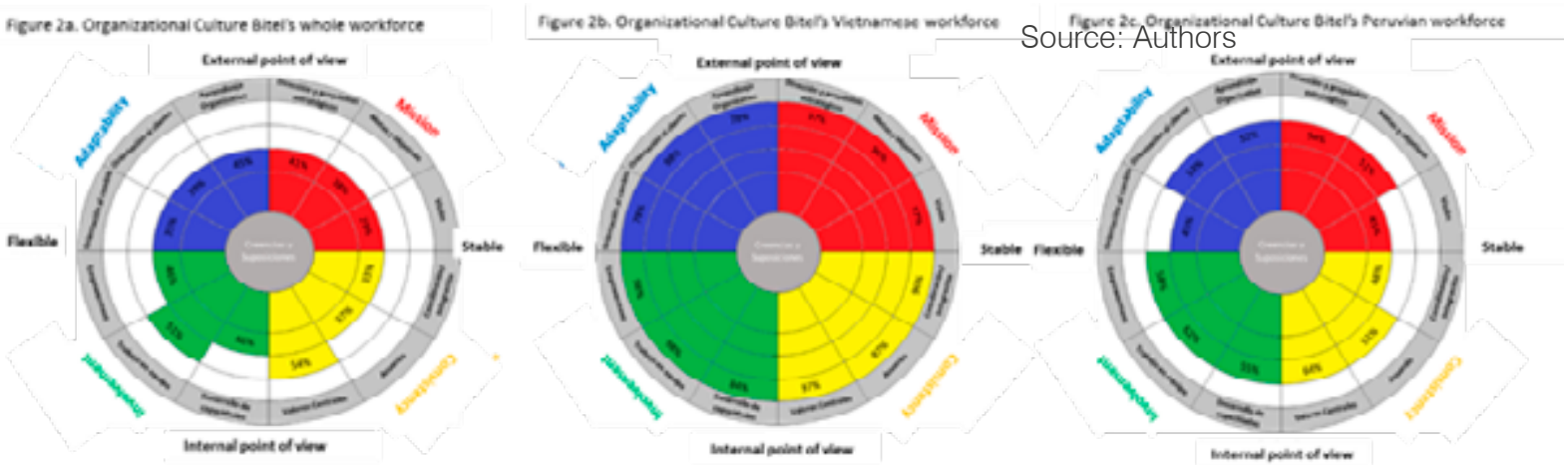

From these charts, we can see that Bitel is middling overall, with some indices marginally stronger than others. In the workforce nationality charts, however, stark differences can be seen between the two groups. Figure 2b shows that the Vietnamese workers rate uniformly high against the organization's culture, while there is a great disparity between these data and those in Figure $2 c$ representing the Peruvian workforce. To enable closer examination, these data were summarized into a table recording the percentages of agreement regarding each cultural quadrant and its indices (see Table 4). 
Table 4 Results of the Denison Model Survey

\begin{tabular}{|c|c|c|c|c|c|}
\hline \multirow{2}{*}{ Quadrant } & \multirow{2}{*}{ Index } & \multicolumn{3}{|c|}{$\%$ of Workforce Score } & \multirow{2}{*}{ Difference } \\
\hline & & Bitel & Peruvian & Vietnamese & \\
\hline \multirow[t]{4}{*}{ Involvement } & & 59 & 48 & 93 & 45 \\
\hline & Empowerment & 58 & 46 & 98 & 52 \\
\hline & Group orientation & 62 & 51 & 95 & 44 \\
\hline & Capability development & 55 & 46 & 84 & 38 \\
\hline \multirow[t]{4}{*}{ Consistency } & & 54 & 41 & 97 & 56 \\
\hline & Core values & 64 & 53 & 97 & 44 \\
\hline & Customer focus & 51 & 37 & 97 & 56 \\
\hline & Coordination and integration & 48 & 33 & 96 & 63 \\
\hline \multirow[t]{4}{*}{ Adaptability } & & 50 & 40 & 84 & 44 \\
\hline & Creating change & 45 & 35 & 78 & 43 \\
\hline & Customer focus & 53 & 39 & 98 & 59 \\
\hline & Organizational learning & 52 & 45 & 78 & 33 \\
\hline \multirow[t]{4}{*}{ Mission } & & 50 & 36 & 97 & 61 \\
\hline & Strategic direction and intent & 54 & 41 & 97 & 56 \\
\hline & Goals and objectives & 51 & 37 & 96 & 59 \\
\hline & Outlook & 46 & 29 & 97 & 68 \\
\hline
\end{tabular}

Source: Authors Mission

These data reveal that the Vietnamese workers show significantly more affinity with the firm's norms, values and strategies. In particular, the Involvement quadrant rates the highest, with the group orientation or teamwork index showing affinity from both sets of workers. Employees also indicate that they are given responsibility and that the organization trusts them. Next is Consistency quadrant, which represents how the employees feel about their connection to the organization, a shared vision and advancing these values. While there is some alignment with core values, there is a large variation between the two groups as to meanings and if and when the firm's values can be put into action. The Adaptability quadrant rates 3rd equal, reflecting that change cannot be easily achieved and reveals issues with the workforce adapting to change and with learning processes. Finally, the Mission quadrant reveals substantial uncertainty, as there are differences across all three of the quadrant's indices, a barrier to improved performance and goal achievement.

\subsection{Examining the effects of culture on Bitel}

While the preceding two sub sections provide the results of a national culture comparative analysis and differences between workforces using the results of the Dennison model, they do not indicate the implications of these results or how they may affect Bitel's operations. Key informant interview transcripts help clarify this and reveal that the differences between national cultures differences and the existence of two groups of workers or subcultures were being recognized and acknowledged. For instance, one interviewee identified the long-term orientation difference as an issue due to Peruvians viewing work as "more in the short term and therefore things are simpler and easier" and acknowledging differences between Peruvians, Bitel's work culture and their expectations, for "the longer one works for Bitel, one begins to handle things better" [Interviewee 3]. 
The respondents also commented on the differences related to uncertainty avoidance, in that when a plan or decision is put in place by a Peruvian manager "everything goes well" resulting in satisfied Peruvian workers. The difference found in uncertainty avoidance was reinforced by another respondent who commented that "for the Vietnamese it is much simpler... the Peruvians do not like change" [Interviewee 5], and another "the Vietnamese are used to the sky being blue one day and red the next, adaptation to change is not a problem for our culture" [Interviewee 7]. This theme was reinforced again with a comment that "the Vietnamese have a culture of discipline and adaption... we adapt very easily" [Interviewee 7], while the Peruvian counterpoint was that it "is necessary to prepare well for each change" [Interviewee 1]. Underpinning these differences are issues related to styles of communication. As one interviewee said, "many times we find things out after they have been launched... the way of communicating is very different between both cultures... [so] we have to adapt to both forms of communication" [Interviewee 2]. Additionally, as Viettel's origins lie in a military hierarchy, roles remain an important feature of its organizational culture, with one respondent remarking, "when someone in the department wants to recommend something to the Vietnamese leadership it is often not taken very well or it can be taken as disrespectful" [Interviewee 2], which is different for local workers as, "Peruvians are not as accustomed to receiving orders and doing them, we tend to question a lot... [and this] betrays that it is very difficult for us to adapt" [Interviewee 3].

The interview analysis also found that Bitel has recognized that worker adaptation and change acceptance are recognized issues and that Bitel has introduced a number of measures to address them. One measure was to refine recruitment and selection processes by becoming "very selective and well formed to find the capabilities that we require as a company" [Interviewee 7]. an onboarding program has been developed in recognition of further difficulties transitioning from a Peruvian workplace to the Bitel culture. This allows employees time to get to know the organization and to integrate more effectively and become more familiar with the way things get done. Another management measure put in place to address cultural differences has affected executive appointments: "[...] now there are many departments and branches that have Peruvian leaders, I dare say that almost $30 \%$ of the leaders are Peruvians" [Interviewee 3].

Bitel has also initiated a number of social and team building events to bridge the cultural divide, such as "soccer championships, corporate parties, the events we have each month. They all serve to get to know both cultures better and therefore help workers who want to improve and develop their capacity to adapt to the other culture and thus be able to obtain better results in their day-to-day work" [Interviewee 6].

\section{Discussion}

As reflected by the results, core cultural differences emanate firstly from the national culture. These are then inserted into Bitel's organizational culture and seem to be amplified through the unique founding culture of Bitel's parent Viettel. However, these differences are acknowledged, with the firm enacting measures to address some of their more debilitating effects.

In terms of national cultural differences, these are initially reflected as uncertainty avoidance in the way firms and their workers address uncertainty. Peruvian companies commonly adopt economic uncertainty strategies characterized by reductions in operating costs and the adoption of low prices to ensure sales and continued operations, leading Peruvian managers to be cautious when conducting business and managing change slowly and consciously (Scott \& Chaston, 2012). 
This avoidance of uncertainty is also reflected in Peruvian management's attitude towards planning, where on many occasions set plans will not be followed, and attention is more likely to be focused on day-to-day activities (Morales, 2013). The lower uncertainty avoidance in the Vietnamese culture is demonstrated by their cultural affinity for flexibility and practicality, leading Vietnamese workers to readily adapt to new tasks or situations quickly (Nguyen \& Aoyama, 2013). Second, there is a difference in long-term orientation, where Peruvian businesses' focus on the present is consistent with their lower score in this dimension, while Vietnam's higher dimensional score has been reinforced by its historical response to the state of war the country endured for almost half a century (Nguyen \& Aoyama, 2013).

Hofstede's other cultural dimensions tend to be expressed in Vietnamese firms through centralized decision-making systems, employees obeying directives without question or debate, tolerance for oversight or inspection, and acceptance of wage differentials between employees and management (Nguyen \& Truong, 2016; Nguyen \& Aoyama, 2013). Given that there is little difference between Peru and Vietnam in these dimensions, these general workplace attributes are similar to the Peruvian work culture of order, with many Peruvian workplaces exhibiting harmony and stability, tending to avoid open conflict or unpleasantness, although this has negative consequences such as passive aggressive behavior and many workplace issues being addressed through gossip and rumor. Peruvian managers also exhibit a certain brusqueness, related to Peru's high power distance, as a means of maintaining social order (Osland et al., 1999).

Secondly, the Denison data reveals the existence of two distinct subcultures within the company based on national culture groupings, where the Vietnamese workforce aligns almost uniformly with the company's culture and the Peruvian workforce reports a consistently lower affinity. These two groupings expose different perceptions and experiences (Alvession, 2002) of Bitel for each group. This is an example of Martin's (2202) fragmentation / differentiation perspectives, where even though Bitel may view its organizational culture as integrated, the data shows this not to be true, which suggests problems for Bitel in terms of achieving alignment between its culture and its performance objectives and provides some insight into why change may be difficult for Bitel.

The organizational culture data also reveal the difficulties Peruvian workers have adapting to change and also how workers in the workplace may receive and respond to managerial direction. It can be seen that the Vietnamese workers are more accepting of stronger direction, which is both a reflection of their national culture and of the parent company's founding as a military venture. This is quite different for the Peruvians, however, whose wish to experience a stable workplace means they are not as accommodating to changes and orders from above. This discomfort regarding managerial style, direction and authority flows both ways. For the Vietnamese it is reversed, with the Vietnamese managers being uncomfortable receiving bottom-up communication, which is, again, a symptom of Bitel's parent being born out of a hierarchical military culture.

However, the interviews revealed that this discomfort has been acknowledged and that measures are being implemented to deal with its effects. This reflects an aspect of Bitel's parent's culture, where Houng (2017) reports that Viettel's attributes of flexibility and will to address difficult situations is considered to be a contributor to the firm's success. Bitel's application of the cultural attributes of its parent firm has been to adapt its recruitment procedures to account for its different work environment and identify candidates who possess better adaptability, teamwork, flexibility and change orientation. This measure, 
As Cartwright and Cooper (1993) and Ralston et al. (2008) contend, when an organization is faced with workers from a national culture that is in opposition to the firm's national culture, it has two options: (i) to continue to enforce the parent organizational culture or (ii) to take the time to understand the differences and implement appropriate measures. Thus, the closing observation of the study is that organizations in similar situations, or those contemplating investments in other countries, may choose to follow Bitel's lead and seek to avoid culturally related performance problems and promote workforce satisfaction by identifying the implications of cultural differences and committing to implementing well planned initiatives to overcome them.

\section{Appendix}

Table 5. Descriptions of Denison's quadrants and their indices

\begin{tabular}{|c|c|c|}
\hline Quadrant & Indices & Description \\
\hline \multirow[t]{4}{*}{ Involvement } & & $\begin{array}{l}\text { Concerns the personal engagement of individu- } \\
\text { als within the organisation, focussing on inter- } \\
\text { nal dynamics and flexibility }\end{array}$ \\
\hline & Empowerment & $\begin{array}{l}\text { People's authority and control over their work to cre- } \\
\text { ate ownership, and sense of responsibility within the } \\
\text { organisation }\end{array}$ \\
\hline & Group orientation & $\begin{array}{l}\text { How much the work is performed or oriented to- } \\
\text { wards common goals for all employees. }\end{array}$ \\
\hline & Capability development & $\begin{array}{l}\text { Continually investing in developing the skills of em- } \\
\text { ployees, to remain competitive and respond to ongo- } \\
\text { ing business needs }\end{array}$ \\
\hline \multirow[t]{4}{*}{ Consistency } & & $\begin{array}{l}\text { Refers to organisational members having } \\
\text { shared values, efficient systems and process- } \\
\text { es, reflecting an internal and stable focus. }\end{array}$ \\
\hline & Core values & $\begin{array}{l}\text { Members of the organisation share a set of values } \\
\text { that creates and sense of identify and clear expec- } \\
\text { tations }\end{array}$ \\
\hline & Customer focus & $\begin{array}{l}\text { The level that the members of an organization are } \\
\text { able to reach agreement and how they reach agree- } \\
\text { ment or reconcile differences. }\end{array}$ \\
\hline & Coordination and integration & $\begin{array}{l}\text { How much the organizational units are able to work } \\
\text { with each other to reach common purposes and that } \\
\text { the organizational boundaries do not disrupted such } \\
\text { working. }\end{array}$ \\
\hline
\end{tabular}




\begin{tabular}{|c|c|c|}
\hline Quadrant & Indices & Description \\
\hline \multirow[t]{4}{*}{ Adaptability } & & $\begin{array}{l}\text { The employees' ability to understand custom- } \\
\text { er needs, to learn new skills and to change in } \\
\text { response to external demands and exhibit flex- } \\
\text { ibility. }\end{array}$ \\
\hline & Creating change & $\begin{array}{l}\text { The organization's ability to create change to adapt } \\
\text { to new environments, respond quickly and anticipate } \\
\text { future changes. }\end{array}$ \\
\hline & Customer focus & $\begin{array}{l}\text { How much organizations seek to understand cus- } \\
\text { tomers, respond to them and sought to satisfy them } \\
\text { and the degree in which the organization is directed } \\
\text { toward satisfying them }\end{array}$ \\
\hline & Organizational learning & $\begin{array}{l}\text { The level of which the organization receives, trans- } \\
\text { lates and interprets environmental signals and cre- } \\
\text { ates opportunities for innovation, gaining knowledge } \\
\text { and developing capabilities. }\end{array}$ \\
\hline \multirow[t]{4}{*}{ Mission } & & $\begin{array}{l}\text { An organisation's purpose and direction that } \\
\text { reflects an external focus and its stability. }\end{array}$ \\
\hline & Strategic direction and intent & $\begin{array}{l}\text { A clear strategic direction that conveys the organi- } \\
\text { zation's is clear how each person may participate. }\end{array}$ \\
\hline & Goals and objectives & $\begin{array}{l}\text { How organisational purposes are integrated with the } \\
\text { strategy and vision of an organization and can be } \\
\text { identified with the work direction of the employees. }\end{array}$ \\
\hline & Outlook & $\begin{array}{l}\text { How an organization involves workers to take a } \\
\text { shared view of a desired future and to identify its } \\
\text { core values, direction and common vision about fu- } \\
\text { ture. }\end{array}$ \\
\hline
\end{tabular}

Source: (Denison, et al., 2014)

\section{References}

- Alvesson, M. (2002). Understanding organizational culture. London: SAGE.

- Arbaiza Fermini, L. (2014). Administración y organización; un enfoque contemporáneo. México City: Cengage Leearning.

- Au, K. Y. (1999). Intra-cultural variation: Evidence and implications for international business. Journal of International Business Studies, 30(4), 799-812.

- Balcazar Guerra, C. (2018). Estrategias para la mejora de la cultura organizacional de Servicios Analíticos Generales SAC aplicando el modelo de Denison. Industrial Data, 21(1), 101-112.

- Capriotti, P. (2009). Branding corporativo. Santiago de Chile: Libros de la empresa.

- Cartwright, S., \& Cooper, C. L. (1993). The role of culture compatibility in successful organizational marriage. Academy of Management Perspectives, 7(2), 57-70.

- Ciuriak, D., Xiao, J., \& Dadkhah, A. (2017). Quantifying the comprehensive and progressive agreement for trans-pacific partnership. East Asian Economic Review, 21 (4), 343-384.

- Dartey-Baah, K. (2011). The impact of national cultures on corporate cultures in organisations. Academic Leadership: The Online Journal, 9(1), 47-56

- Denison Consulting. (2019). Organizational Culture Surveys. From Denison Consulting website: https:// www.denisonconsulting.com/culture-surveys/ [Accessed 24/04/2020]

- Denison, D., Nieminen, L., \& Kotrba, L. (2014). Diagnosing organizational cultures: A conceptual and empirical review of culture effectiveness surveys. European Journal of Work and Organizational Psychology, 23(1), 145-161.

- Ehrhart, M., Schneider, B. \& Macey, W. (2014). Organizational climate and culture. New York: Routledge.

- García Álvarez, C. M. (2006). Una aproximación al concepto de culturao. Universitas Psychologica, 5(1), 163-174. 
- Hofstede, G. \& Hofstede, G.J. (2005), Cultures and organizations: Software of the mind, 2nd Ed. McGrawHill, New York, NY.

- Hofstede, G. (1985). The interaction between national and organizational value systems [1]. Journal of Management Studies, 22(4), 347-357.

- Hofstede, G. (1984). Cultural dimensions in management and planning. Asia Pacific Journal of Management, $1(2), 81-99$

- Hofstede, G. (1980). Culture's consequences: International differences in work-related values. Beverly Hills, CA: Sage Publications.

- Holden, N. (2002). Cross-cultural management: A knowledge management perspective. London: Pearson Education.

- Huong, T. (2017). Viettel: Success story in business and defence. Vietnam Investment Review [Online]. From: https://www.vir.com.vn/viettel-success-story-in-business-and-defence-50601.html [Accessed
[A 13/08/2020].

- Jamieson, N. L. (1995). Understanding Vietnam. University of California Press.

- Julien, H. (2008). Content analysis. In L. M. Given (Ed.), The Sage Encyclopedia of Qualitative Research Methods (pp. 120-122). Thousand Oaks, CA: Sage Publications.

- Khan, M. A., \& Law, L. S. (2018). The role of national cultures in shaping the corporate management cultures: A three-country theoretical analysis. In Organizational Culture Organizational Culture, Edited by Jolita Vveinhardt. IntechOpen. [Online] available from: https://www.intechopen.com/books/organizationalculture/the-role-of-national-cultures-in-shaping-the-corporate-management-cultures-a-three-countrytheoretic

- Kim, S., \& McLean, G. N. (2014). The impact of national culture on informal learning in the workplace. Adult Education Quarterly, 64(1), 39-59.

- Koontz, H., \& Weirich, H. (2007). Elementos de administración: Un enfoque internacional. Mexico City: McGraw-Hill.

- $\quad$ Kotter, J. P. \& Heskett, J. L. (2008). Corporate culture and performance. New York: The Free Press

- Lepeley, M. T. (2020). Human Centered Management: 5 Pillars of Organizational Ouality and Global Sustainability. Abingdon, UK: Routledge.

- Martin, J. (2002). Organizational culture: Mapping the terrain. Thousand Oaks, CA: Sage Publications.

- Martinez Ramos, P. J., Montoya Arévalo, B. E., Marquez Murga, S. I. (2011). Diagnóstico de la cultura organizacional como un elemento clave de la mejora organizacional: dos casos de aplicación en Chihuahua. In Proceedings of the XV Congresso Internacional de Investigaciones en Ciencias Administrativas, Boca del Rio, Mexico, May 17-21. Available from http://www.academia.edu/download/56634322/12_03_cultura_ organizacional.pdf [Accessed 17/04/2020]

- Montero Pacheco, S. (2018). Diagnóstico de la cultura organizacional y su relación con el desempeño laboral en la empresa Quintero Leather S.A.S utilización del modelo Denison. (Unpublished master's thesis). Available from https://ciencia.lasalle.edu.co/maest_administracion/496 [Accessed 17/04/2020].

- Morales, 0. (2013). Gestion de la diversidad cultural en el entorno de negocios peruano. Tiempo de Opinión 4(6), 54-61.

- Nguyen, M., \& Truong, M. (2016). The effect of culture on enterprise's perception of corporate social responsibility: The case of Vietnam. Procedia Cirp, 40, 680-686.

- Nguyen, N. T. D., \& Aoyama, A. (2013). Exploring cultural differences in implementing international technology transfer in the case of Japanese manufacturing subsidiaries in Vietnam. Contemporary Management Research, 9(1), 13-34.

- Olie, R. (1990). Culture and integretion problems in international mergers and acquitions. European Management Journal, 8(2), 206-215.

- Omar, A., \& Urteaga, A. F. (2010). El impacto de la cultura nacional sobre la cultura organizacional. Universitas Psychologica, 9(1), 79-92.

- Osland, J. S., De Franco, S., \& Osland, A. (1999). Organizational implications of Latin American culture: Lessons for the expatriate manager. Journal of Management Inquiry, 8(2), 219-234.

- Palys, T. (2008). Purposive Sampling. In L. M. Given (Ed.), The Sage Encyclopedia of Qualitative Research Methods (pp. 697-698). Thousand Oaks, CA: Sage Publications.

- Pelled, L. H., \& Xin, K. R. (1997). Work values and their human resource management implications: A theoretical comparison of China, Mexico, and the United States. Journal of Applied Management Studies, 6(2), $185-$

- Pettigrew, A. (1979). On studying organizational cultures. Administrative Science Quarterly, 24(4): 570-581.

- Ralston, D. A., Holt, D. H., Terpstra, R. H., \& Kai-Cheng, Y. (2008). The impact of national culture and economic ideology on managerial work values: A study of the United States, Russia, Japan, and China. Journal of International Business Studies, 39(1), 8-26.

- $\quad$ Reyes-Martínez, L., Barboza-Carrasco, M. Y., \& Vicuña-Tapia, H. (2017). Diagnóstico Cultura Organizacional de la Empresa Grupo Fadomo Reproser, S.A. De C.V. Revista de Desarrollo Económico, 4(12), 67-78 
- Saha, A., Thorpe, J., O'Flynn, P., \& H. Bucher. (2020). Designing for impact: South-South trade and investment. Geneva: International Trade Centre.

- Schein, E. (1992). Organizational culture and leadership. San Francisco: Jossey-Bass.

- Schneider, B., Ehrhart, M. G., \& Macey, W. H. (2013). Organizational climate and culture. Annual Review of Psychology, 64, 361-388.

- Schneider, S. C., \& Barsoux, J. L. (1997). Managing cultural differences, 8th Ed. Burlington, MA: Butterworth Hienmann.

- Schwartz, S. H. (1999). A theory of cultural values and some implications for work. Applied Psychology, 48(1), 23-47.

- Schwartz, S. H. (2004). Mapping and interpreting cultural differences around the world. In H. Vinken, J. Soeters, \& P Ester (Eds.), Comparing cultures, Dimensions of culture in a comparative perspective (pp.4373). Leiden: The Netherlands: Brill.

- Scott, G. J., \& Chaston, I. (2012). Culture and innovation in Peru from a management perspective. Journal of Global Initiatives, 7(2), 131-145.

- Serna, H. (2008). Gerencia Estratégica: Teoría-Metodología. Alineamiento, y mapas estratégicos.(10a ed.). Bogotá: 3ER Editores.

- $\quad$ Singh, D., Pattnaik, C., Lee, J. Y., \& Gaur, A. S. (2019). Subsidiary staffing, cultural friction, and subsidiary performance: Evidence from Korean subsidiaries in 63 countries. Human Resource Management, 58(2), 219-234.

- Trompenaars, A., \& Hampden-Turner, C. (1998). Riding the Waves of Culture: Understanding Cultural Diversity in Business, 2nd Ed. New York, NY: McGraw Hill.

- Tylor, E. B. (1871). Primitive culture: Researches into the development of mythology, philosophy, religion, art, and custom (Vol. 1\&2). London: J. Murray.

- United Nations Conference on Trade and Development (UNCTAD). (2019a). Regional FDI at a glance: Latin America and the Caribbean. Available from https://unctad.org/Sections/dite_dir/docs/WIR2019/ WIR2019_FDI_Latin_America_and_the_Caribbean_en.pdf (Accessed 14/08/2020).

- United Nations Conference on Trade and Development (UNCTAD). (2019b). Regional FDI at a glance: Developing Asia. Available from https://unctad.org/Sections/dite_dir/docs/WIR2019/WIR2019 FDI Developing_Asia_en.pdf (Accessed 14/08/2020).

- Viettel. (2020). About Viettel. From http://viettel.com.vn/en/about\#about-viettel [Accessed 17/04/2020].

- Vy, H. (2017, 19 Sept). Viettel's Peru branch makes \$45-million 4G investment. Vietnam Investment Review [Online]. From: https://www.vir.com.vn/viettels-peru-branch-makes-45-million-4g-investment-53050.html [Accessed 24/04/2020].

- Yamakawa, P., Rees, G. H., Salas, J. M., \& Alva, N. (2013). The diffusion of mobile telephones: An empirical analysis for Peru. Telecommunications Policy, 37(6-7), 594-606.

- Z Zhang W., \& Creswell J. W. (2013). The use of "mixing" procedure of mixed methods in health services research. Medical Care, 51(8), e51-e7. 